\title{
CORRUPTION, THE STATE AND THE CHALLENGE OF SOCIAL STABILITY IN NIGERIA
}

\author{
Rev. Fr. Dr. Lawrence N. Nwankwo \\ Anambra State University, Igbariam Campus \\ *http://dx.doi.org/10.4314/ujah.v14i3.4
}

\section{Abstract}

Nigeria, and indeed many African countries, rank high on both the corruption and failed state indices. This means that there is high incidence of corruption and more likelihood of social instability. Beside the feed back loop between corruption and social instability, scholars use different approaches to make sense of the endemic nature of corruption and the volatility of the Nigerian polity. One of such approaches is the underdevelopment theory which focuses mainly on socio-economic factors. Another approach focuses on cultural issues. Without denying the usefulness of these approaches, it is my view that the mode of introduction of the State as the socio-political structure for organizing society and the nature of the relationship that has developed between the State and the Nigerian society contribute to the endemic nature of corruption and the social instability that plagues the country. A healthier Nigerian polity can only emerge if these elements are reviewed and corrected.

\section{Introduction}

The world continues to witness the fall-out from the Arab Spring. Many governments in that region have been overthrown. In some cases, as in Egypt, regime change was easy but in others, it only came after a protracted and 
destructive war. Libya comes to mind. Presently, Syria is the flashpoint. The government of Bashar Al-Assad in Damascus has held out and the situation in the country has deteriorated to what may be described as a civil war. Notwithstanding the fact of regime change in many of the countries in the region, social stability has not returned. The recent overthrow of the government of Mohammed Morsi in Egypt shows that the rumbling goes on. In the Democratic Republic of Congo (DRC), one is presented with a similar but more harrowing scenario. Since the end of the regime of Mobutu Sese Sekou, the country has almost virtually disintegrated. In the DRC, the integrity of the State is already compromised as rebels control large areas and the state has been impeded from performing its function as the over-arching authority within a sovereign territory with the responsibility of protecting life and property, legislating, regulating and policing the public domain. Nearer home in Nigeria, the Boko Haram insurgence and the prediction of a possible break-up of the country in 2015, have placed the issues of social stability at the front burner.

Social stability does not in any way imply immobility and permanence. Moreover, social instability is not a problem that started in modern times. There have always been great movements in the affairs and fortunes of peoples and nations. In the past, great empires had arisen, redrawn the existing map and then fallen and its peoples assimilated into other geopolitical entities. There has always been movement: groups coalesce into socio-political entities and others dissolve into its component parts. While this has always been going on, what changed, especially since the $17^{\text {th }}$ century, is the context of organization of human society with a corresponding change in the manifestation and resolution of social change. Before the emergence of the sovereign territorial state, a warlord could 
wake up and annex surrounding territories sending the original inhabitants into exile or making them vassals. Discontented groups within a polity could seceded or transfer their allegiance to another leader with the military might to protect them. Such instances are documented in the Hebrew Scriptures. For example, David sacked the Jebusites, captured and made Jerusalem his capital (2 Sam 5:6-12); Jeroboam the son of Nebat, at the instigation of Prophet Ahijah led a revolt against Rehoboam and seceded with ten of the twelve tribes of Israel (1 Kings 12). Tiglath-Pileser king of Assyria marched against the Northern Kingdom, captured Samaria and deported its inhabitants to Assyria while resettling others in that territory (2 Kings 17:5-6, 24). All these show great mobility and instability.

The establishment of sovereign states as the geopolitical unit of organization did not diminish instability. Rather, it changed its dynamics. It resulted in what can be referred to as 'containerization.' States are like containers holding together many and different people. As the temperature and pressure are increased, the molecules keep bouncing off with greater force on the walls of the container but have little means of escape. This is unlike how it used to be before the advent of the sovereign state. Social and political pressures were eased through geographical movement. Economic hardship, persecution or other social problems could make a population to relocate to another place, even if the place is previously occupied. This was part of the context in which the Boers came to South Africa and many people came over from Europe to the United States of America. Today, such ease of movement and easy way of restoring equilibrium in a society are no longer available. A geopolitical entity bedeviled by destabilizing economic and political problems - high rate of 
unemployment, insecurity to life and property, bad leadership, ethnicity - is expected to solve its internal problem. Breaking up of such geopolitical entities is often only remotely considered. The result is that things deteriorate in such territories or regions till the near state of anarchy as witnessed in Somalia.

In contrast to the deterioration in Somalia, for example, the promotion of stability has been connected with the building up of regional integration and cooperation. In the European Union, for example, the effort is at the integration of a whole region into a common market with common currency and corresponding regional system of political machinery. This presupposes relative stability within the borders of the constituents States that make up the Union. Thus, while some regions of the world are grappling with the "problem of order," that is, with the challenge of achieving integration and stability within the borders of the constituent States, others are moving beyond this and are creatively crafting a complex supra-State system of economic and social inter-dependence of peoples to forestall any resort to disruptive skirmishes that resulted in the World Wars.

It is interesting to note that the sovereign State has not always existed in history. It emerged with the Peace of Westphalia which was a series of treaties signed between May and October 1648 in Osnabrück and Münster which ended the thirty year war in Holy Roman Empire and the eighty year war between France and the Dutch Republic. As one reads up in the Wikipedia, the Peace of Westphalia initiated a new system of political organization based on the sovereign state which is a nonphysical juridical entity recognized in International law and represented by a centralized government which has 
supreme independent authority in a defined geographic area. This political system represented the triumph of sovereignty over empire and privileged national rule over the personal rule of kings. It also represented a prejudice in international affairs against external interference in another nation's domestic affairs and favored self-determination.

As can be seen, this political system was crafted as a solution to social instability created by the thirty year war. But as it solved one problem it created others. In its birthplace - Europe - it stoked the fire of nationalism. Nations, that is, groups with a common history and language, strove to organize themselves as sovereign states. The common identity was turned into what Wrong, D.H (1994:203) calls "invidious distinction” vis-à-vis other groups. This is a situation when difference is perceived as antagonistic opposition, as was the case in the Nazi ideology of a superior Aryan race. This ideology was behind the Holocaust and the carnage of World War II. It is also important to note that the project of the European Union alluded to above, was conceived partly to obviate the rise of such nationalism again. That is, by building an economic network and facilitating cross-border movement, it is hoped that the interdependence and interaction between the various peoples of Europe would mitigate the allurement of extreme nationalism that generates conflict and instability.

As Europe tackled nationalism created by the State, other difficulties were fomented in other lands where it was transplanted. It is the view of some scholars, as underscored by Engelbert (1997:768) that "the nature of the state [is] the crucial variable in understanding the deviances" that one observes in Africa, and in Nigeria, to particularize further. This is the point of this reflection. My argument is that the nature of 
Corruption, the State and the Challenge of Social Stability in Nigeria - Rev. Fr. Dr. Lawrence N. Nwankwo

the post-colonial state in Africa has to be understood for a proper appreciation of the roots of the corruption and instability that plague Nigeria and the African continent at large.

\section{The Post-Colonial State in Africa}

The post-colonial state in Africa is a descendant of the colonial state. The model of relationship between the state and the society during the colonial era was one of domination and exploitation. Not much was changed in this model of relationship in the post-colony. Rather, events, actions and decisions after the end of the colonial rule have reinforced some negative trajectory.

The insight into the implication of the state in the problems of corruption and instability in Africa is not new. In an article with the interesting title, "The Contemporary African State: neither African nor State," Pierre Engelbert (1997) reviews the writings of four scholars who have studied the state in Africa. In order to show that the state in Africa does not measure up to what it should be, they have come up with various labels: shadow state (William Reno); rhizome state (Jean-François Bayart); bifurcated state (Mahmood Mamdani) and disconnected state (Mamadou Dia). The analyses behind these conclusions are prefixed on the exogeneity of the state, that is, the view that the State in Africa is an imported institution grafted onto the African soil. As Engelbert (1997:767) puts it, "it is because it is not African that the African state is not a state. In observing the numerous instances of state failure in Africa and the massive evidence of societal exit, it should be apparent that these pathologies derive from the very exogeneity of the state, its lack of embeddedness, its divorce from underlying norms and networks of social organization. 
Patterns of predation, neo-patrimonialism, rent seeking, urban bias, and administrative decay can be thought of as deriving from the legitimacy deficit of the African state." Continuing, Engelbert (1997) quoted Chinua Achebe who wrote that the problems of African development are linked to the fact that "in the affairs of the nation there was no owner, the laws of the village became powerless"

While this argument from the point of view of the exogeneity of the African state has a lot to commend it, it stops at telling us what happened in the past but does not offer any insight into what is happening now and how to tackle the malaise. To address these, I want to appropriate Bayart's imagery of a rhizome state. But before engaging this image, the story ascribed to Colin Powell, the U.S Secretary of State under President George W. Bush can help prepare the ground for my appropriation of the image of the rhizome state. The story is that after his stint at the White House, Colin Powell as a private citizen was traveling. At the airport, he was subjected to a thorough security search like every other traveler. At the end of the search, the young officer pleasantly wished him, "have a safe flight General!" It struck Colin Powell that the young officer had all along known who he was. Yet as a functionary of the State, he had to do his duty without presuming to waive the requirement on his recognition of this erstwhile public figure. Colin Powell also did not insist on being treated differently. In this story, one sees that the action of both the young officer at the airport and Colin Powell were structured by the laid down rules of the State. Although not a physical entity, the state's influence is both intensive and extensive. It is this penetrating reach and structuring of action in line with the law that rhizome states lack. 
Bayart J.-F., (1993) borrowed the concept of the rhizome from Gilles Deleuze and Félix Guattari who developed it in contrast to images of the tree and the root. Bayart applies it to articulate the relationship between the state and society. While the tree and root stand out as definable and distinct from all around it, "there are no points or positions in a rhizome, such as those found in a structure, tree or root. There are only lines." (Deleuze \& Guattari, 1987:9). The rhizome continually mingles and intertwines. Without going into the post-modern sensibilities behind this imagery, the imagery draws attention to the fact that the post-colonial state in Africa is not like a tree or root definable and distinct from the society. There is an entanglement between both or what Bayart (1993) calls a reciprocal assimilation of one to the other. Unlike the statesociety relation discernible in the story about Colin Powell and the airport officer, in post-colonial Africa, state agents and officials have so much discretional powers that it might be better to speak of a personalization of the apparatuses of state power. It is this personalization of state power that is at the basis of the widespread corruption and the seeming intractability of this problem.

\section{Corruption: Conceptual Analysis}

Corruption is a world-wide scourge and it has a long documented history. In a fourth century B.C treatise on public administration in India Arthasastra written by Kautiliya quoted in Pranab Bardhan (1997:1320), it is observed that "just as it is impossible not to taste the honey (or the poison) that finds itself at the tip of the tongue, so it is impossible for a government servant not to eat up, at least, a bit of the king's revenue. Just as fish moving under water cannot possibly be fount out either as drinking or not drinking water, so government servants employed in the government work cannot 
be found out (while) taking money (for themselves)." This notwithstanding, every government and every society in the world is waging an on-going battle against it.

Corruption manifests itself in different ways in different contexts. As Friedrich C.J (1972) puts it, that "corruption is endemic in all forms of government is practically certain. But that there are striking differences in the extent of corruption between governments ... is equally patent." Some societies have built up strong institutions that are able to forestall and address the issues of corruption as they arise. In others, corruption has become part of the fabric of the society so much so that despite their protestations, people feel themselves pressured to avail themselves of corrupt practices for survival or for other needs. This recalls the saying in Igbo "a na-alu olu a na-alu ulu, mana ulu akana olu" (as one works, one should be helping oneself from what is provided, but let what one appropriates not exceed the amount of work done). This shows a level of accommodation of corruption or rather realism as regards it inevitability.

A direct connection between corruption and social instability can be easily made. In its website, the ICPC (Independent Corrupt Practices and other Related Offences Commission Corruption) notes, "Corruption in Nigeria undermines democratic institutions, retards economic development and contributes to government instability. Corruption attacks the foundation of democratic institutions by distorting electoral processes, perverting the rule of law, and creating bureaucratic quagmires whose only reason for existence is the soliciting of bribes." In other words, corruption leads to underdevelopment. When merit is thrown overboard or when the resources of the State are diverted into private pockets, instead 
of used for public good such as job creation, the result is mediocrity, unemployment and an army of restive young people, alienated from the State. These could take to crime or be recruited for the purpose of anti-State activities. The net result is insecurity and instability. In a sense, corruption which is exacerbated by the history and praxis of the post-colonial African state, has contributed to the instability in the continent. Before we go further, let us clarify the concept of corruption.

Corruption is much more than the offering and acceptance of bribes. Besides the general idea of corruption as decay, perversion from an original state of purity, corruption entails the subversion of the right order or relationship between the personal and the communal or public (Rose-Ackerman, 1999). This sense comes out clearly in the three basic models that are in use in the conceptual analysis or definitions of corruption. These models are: the public-office-centred, the marketcentred and the public-interest centred definitions.

In a public-office-centred definition, corruption is highlighted as deviations from the norms binding upon public office holders. This is the model that underlies the definition by Nye J.S (1967:417) for whom corruption is "behaviour which deviates from the normal duties of a public role because of private-regarding (family, close private clique), pecuniary or status gains; or violates rules against the exercise of certain types of private-regarding influence. This includes such behaviour as bribery (use of reward to pervert the judgement of a person in a position of trust); nepotism (bestowal of patronage by reason of ascriptive relationship rather than merit); and misappropriation (illegal appropriation of public resources for private-regarding uses)." 
In a market-centred definition, corruption is seen in terms of a quid-pro-quo relationship. One offers something in order to gain another thing. As Leff N., (1964:8) puts it, "corruption is an extra-legal institution used by individuals or groups to gain influence over the actions of the bureaucracy." The outcome of such influence is that individuals and groups get privileged information and participate in the decision making process to a greater extent than would otherwise be the case. An example of this is when the criminals wield influence over security personnel and in this way get classified information that help them evade capture.

Finally, the public-interest centred definition draws from the distinction between public and private interest. Corruption from this perspective involves the perversion of public interest on account of inducement of the public office holder. As Friedrich C.J., (1972) puts it, "the pattern of corruption can be said to exist whenever a power-holder who is charged with doing certain things, i.e., who is a responsible functionary or office-holder, is by monetary or other rewards not legally provided for, induced to take actions which favor whoever provides the rewards and thereby does damage to the group or organization to which the functionary belongs, more specifically the government."

\section{The State and Corruption in Africa}

As stated above, the argument of this paper is that the history and praxis of the sovereign state structure in Africa is contributory to the scale of corruption in the continent. I will show this in three steps. First, the extraversion of the colonial state in Africa undermined accountability and laid the basis for the corruption of the post-colonial state. Second, the sovereign state structure made government distant from the community 
and demobilized the traditional checks and balances while truncating the western system of checks. Third, the multiethnic composition of the emergent states encouraged the move towards centralization and the consequent rise of clientelism and what has been called neo-patrimonial politics. These labels - clientelism and neo-patrimonialism - are different ways of saying that the rationality that drives the post-colonial state in Africa does not measure up to what should drive a sovereign state. It is my view that this is the basis of the corruption that is rampant. Let us then look at the three points outlined more closely.

To speak of the extraversion of the post-colonial state is to draw attention to the fact that the states in Africa were set up not to cater for the needs of the citizens or better still the colonial subjects, but rather for the needs of the colonial masters. The administrative structure set up was geared towards the maximization of the extraction of raw material and human labour. In Igboland, for example, warrant chiefs were appointed and entrusted with the maintenance of law and order (Afigbo, 1972). They were backed up with colonial might in order for them to mobilize human labor for the colonial projects. In order words, the administration was organized for the fulfillment of the needs of the colonialists. Worthy of note is the fact that these warrant chiefs were often imposed on the people. They were not people selected by the people. Sometimes, they were people of questionable characters whose qualification include readiness to serve the colonialists and ruthlessness to quell any revolt. Consequently, some of these chiefs did not feel themselves accountable to their communities but to the colonial masters. The colonial masters also turned blind eye on the excesses of the warrant chiefs. Their high-handedness and abuse of power were ignored as 
long as they enforced the colonial order and mobilized the labour needed to extract raw materials for the industries at the metropolis.

The extraversion of the colonial state and the inheritance of this organizational structure in the post-colonial state effectively disabled the checks and balances in traditional society without transplanting the checks and balances embedded in the new system. In the traditional set up, authority is inscribed in a ritual world and there were other institutions that moderated the exercise of this authority. Such moderating institutions ensured that authority is exercised for the good of the community. This synthesis was disrupted. The warrant chiefs, for example, ruled by the fiat of the colonial powers and were not accountable to their people. Political authority was taken from the community and reposed in the hands of warrant chiefs whose only claim to legitimacy was the fact that they were in the favor of the colonial masters. In other words, the relationship between the warrant chief and the colonial officer is that of a client to a patron. The warrant chief's position is secured not by any statutes but by the personal will of the colonial officer.

As the nationalist fervor increased in the late $20^{\text {th }}$ century, the colonialists organized series of constitutional conferences and finally handed power over to the Africans. The colonial state is thus mother to the post-colonial state and inherited many elements therefrom. Indeed, the foundation and basic outline of the post-colonial state was laid in the colonial era. For example, the post-colonial state inherited the boundaries defined by colonialism. One recalls the Berlin Conference and the partitioning of Africa. This exercise was undertaken not for the interest of the Africans but rather to obviate conflict 
Corruption, the State and the Challenge of Social Stability in Nigeria - Rev. Fr. Dr. Lawrence N. Nwankwo

between the European powers. Some of these boundaries brought various disparate ethnic groups into a unit. Some policies of the colonial administration created imbalance between the ethnic groups, exacerbated suspicion between the groups and introduced a dynamics in the post-colonial state that has tended towards centralization. In the prevailing climate of the Cold War, many of the post-colonial states quickly adopted one-party rule or military dictatorship.

In the case of Nigeria, the civil war and the oil boom transformed the centralization into what Chukwuma Charles Soludo (2012) calls "unitary federalism." According to him, "literally everything flows from the centre. Local governments are 'created' from the centre; $90 \%$ of revenues come from the centre; public service throughout the country including higher educational institutions operates under unified salary schemes." Part of the raison d'être of this unification is traced to the emergence of oil as the dominant revenue source in Nigeria and the creation of the institutional arrangement for sharing the rent. At the Federal, State, Local government and ward levels, governance became synonymous with distribution of rent and other resources. Because of the enormous resources involved, capturing and retaining political power became a "do-or-die affair." Being in charge of the distribution of the rent, the political office holder often allocated these resources according to their subjective preferences and for their own benefit. They sometimes support interventions that do not maximize benefit for all but to themselves, their supporters and cronies. In a transliteration of the Igbo saying, the office holder is the one holding the yam and the knife and slices off and distributes to each as much as pleases him or her. The discourse is therefore not in terms of one's right or due as enshrined in the 'international code of best practices' but in 
terms of what is pleasing to 'oga' or 'madam.' These officeholders therefore become patrons and the citizenry become their clients and their relationship is not regulated by codified rights and duties but by the code of privileges and inducements given for personal benefits. It is such a relationship that is variously described as patrimonialism or clientelism. That is, the relationship between the State and its functionaries on the one hand, and the rest of the polity on the other hand, is not what it should be. Instead of being regulated by rights and duties, instead of the allocation of resources and distribution of welfare being guided by the common good, narrow, personal and ethnic considerations prevail.

What is being described above is the corruption of the State, the subversion of what the State should be and how it should operate. Worse still, the dynamics described aids and abets corruption in the wider society. Other institutions are weakened and infused with similar rationality. The net result is an emphasis on and mobilization of particular identities ethnicity, geo-political, religious etc - for the attainment of personal, sectional and particular interests at the expense of the common good. This creates instability in the polity as these particular identities are often brazenly deployed in the contestation for power, control and other privileges.

\section{Fighting Corruption and Working For Stability}

So far, our analysis may give the impression that we are engaged in a blame game: find who to blame for your woes. In this case, blame the State system of political organization, as crafted and foisted on Africa by the colonialists and then make a link to instability. This is a caricature of what we set out to do in this work. What is closer to our intention is to draw attention to the historically evolving structural elements that 
shape our understanding and actions. This is not intended to eclipse human agency, that is, the fact that human beings contribute through their decisions, omissions and actions to the constitution and continued re-constitution of the deplorable situation. This notwithstanding, an in-depth analysis of the structural elements that provide the context within which human beings deploy their actions is helpful even for a meaningful exercise of agency.

In the light of the above, it has to be accepted that the sovereign state system of political organization has come to stay. The fact that the post-colonial state is heir to the colonial arrangement also cannot be denied but this can no longer be given as excuse. The best that can be done is draw valuable lessons from a reflection on the historical events and to tinker with the heritage in ways that counter the dysfunctional incentive that have arisen through time. That is why Chukwuma Charles Soludo (2012) argued for a shift from a unitary federalism to fiscal federalism. The differences between the two types of federalism are of two kinds. First, while unitary federalism seeks to establish a unitary system of command and control, fiscal federalism seeks to encourage difference and to harness competition among the various peoples and groups within its polity for economic group. The second set of difference is that unitary federalism is geared towards the sharing of resources from rent on mineral resources, fiscal federalism aims at encouraging businesses and in this way creating employment opportunities and generating revenue through taxation. The transition from unitary to fiscal federalism would also demand administrative restructuring and rationalization that would free up resources hitherto spent as recurrent expenditure for capital projects. Finally, a transition from unitary to fiscal federalism would 
remove the dysfunctional incentive to capture political power by all means since political power would be faced, more and more with the challenged of baking rather than of sharing the national cake.

There are numerous agencies, apart from the police and the judiciary charged with fighting corruption in Nigeria. EFCC (Economic and Financial Crimes Commission) and the ICPC (Independent Corrupt Practices and other Related Offences Commission) stand out among others. Yet, the effects of the efforts of these commissions are rarely seen. This gives rise to two divergent reactions. While the first sees this as evidence of how widespread and endemic corruption is, the other is dismissive of these efforts as directed at small fries when the big fish strut the stage unmolested. There is usually the question about who and how the watchmen are to be watched. That is, how to check those entrusted with the job of fighting corruption so that they do not themselves aid and abet corruption.

The challenge of how to watch the watchman brings us to a consideration of the role of civil society. It is true that the characterization of rhizome state makes one aware of the reciprocal assimilation of the state and the society and the consequent weakness of the state and its institutions, it is still incontrovertible that a society gets the level of transparency and accountability that it is able to demand for. It is equally important to note that it is not necessary that the whole populace be committed to the fight against corruption. What is required is for some members of the society to organize themselves and be committed to using the legal and institutional mechanisms available to make a change in their society. 
Corruption, the State and the Challenge of Social Stability in Nigeria - Rev. Fr. Dr. Lawrence N. Nwankwo

Finally, the widespread nature of corruption makes it seem that the formation of conscience does not stand a chance since children are being raised in morally corrosive environment. This spreads a form of pessimism disillusionment and some people are led to deploy the self-serving slogan "if you cannot beat them, then join them!" Pessimism is however a luxury that people can ill afford. Moreover, there are other reasons for hope. For example, my young nephew, instead of joining others in examination malpractice was shocked that kids like himself were not self-confident and preferred to cheat rather than task their brain to pass an entrance examination to a choice secondary school. Events such as this show that all hope is not lost. What is needed is for more people to tap into their reserve of hope in order to engage in providing the necessary checks that would make both our state officials and apparatus to work according to established laws and for the common good.

\section{Concluding Reflection}

What is constant is change. Social stability therefore does not mean immobility. Instability ensues when the socio-political and economic framework of common life in a polity is being undermined. Our argument has been that the introduction of the State in Africa disabled pre-existing frameworks of the organization of society and introduced other elements that have resulted in the post-colonial state inability to stand out over and against the society, to structure the public domain for the common good. The result is a State with weak institutions and apparatuses for governance that are vulnerable to personalization and privatization. This is the root of corruption that has bedeviled the polity and has unleashed destabilizing forces giving rise to further weakening of the State. 
In line with the interplay of structure and agency in social action, it is clear that the way forward would entail adjustment of structures as well as attitudinal changes. Restructuring the polity towards fiscal federalism and increased emphasis on civic education and value re-orientation are the two pronged approaches needed for social stability in the long term.

\section{References}

"Peace of Westphalia" in

http://en.wikipedia.org/wiki/Peace_of_Westphalia accessed on July 20, 2013.

Afigbo A.E., Warrant Chiefs: Indirect Rule in Southeastern Nigeria 1891-1929 London: Longman, 1972.

Bardhan P., "Corruption and Development: A Review of Issues," Journal of Economic Literature 25 (1997) 1320-1334.

Bayart, J.-F, The State in Africa: The Politics of the Belly, trans. Elizabeth Harrison. London: Longman, 1993.

Deleuze G., \& Guattari, F., A Thousand Plateaus. London: Continuum, 1987.

Engelbert, P., "The Contemporary African State: neither African nor State," Third World Quarterly 18:4, (1997) 767775.

Friedrich, C.J., "Corruption Concepts in Historical Perspective," in Political Corruption: Concepts \& Contexts, ed. Arnold J. Heidenheimer \& Michael Johnston (New Brunswick: Transaction Pub. 2002) 15-23.

ICPC, http://icpc.gov.ng/ accessed on July 15, 2013. 
Corruption, the State and the Challenge of Social Stability in Nigeria - Rev. Fr. Dr. Lawrence N. Nwankwo

Leff N., "Economic Development through Bureaucratic Corruption," American Behavioral Scientist 8:3(1964) 8-14.

Nye, J.S., "Corruption and Political Development: A CostBenefit Analysis" American Political Science Review 61 (1967) 417-427.

Rose-Ackerman S., Corruption and Government: Causes, Consequences and Reform. Cambridge: Cambridge University Press, 1999.

Soludo C.C., "Nigeria: Towards Creation of Incentives and Structures for Good Governance," Paper presented as the 2012 Annual Conference of the Faculty of Arts, Nnamdi Azikiwe University Awka, May 3, 2012.

Wrong, D.H., The Problem of Order: What Unites and Divides Society. London: Harvard University Press, 1994. 